\title{
NPM1/RARA Long Fusion Gene
}

National Cancer Institute

\section{Source}

National Cancer Institute. NPM1/RARA Long Fusion Gene. NCI Thesaurus. Code C101064.

A fusion gene $(\sim 2.1 \mathrm{~kb})$ that results from a chromosomal translocation $\mathrm{t}(5 ; 17)(\mathrm{q} 35 ; \mathrm{q} 21)$

which fuses the first 484 nucleotides of the NPM1 gene to exon 3 of the RARA gene.

This rearrangement is rare and is associated with acute myeloid leukemia. 